\title{
Recent advances in understanding and treatment of Parkinson's disease
}

\author{
Arjun Tarakad ${ }^{1}$ Joseph Jankovic (iD ${ }^{1 *}$ \\ ${ }^{1}$ Parkinson's Disease Center and Movement Disorder Clinic, Department of Neurology, Baylor College of Medicine, 7200 Cambridge, Suite 9A, Houston, \\ TX 77030-4202, USA
}

\begin{abstract}
Though primarily a sporadic condition, Parkinson's disease is increasingly recognized to be a multifactorial disease with a strong genetic component. At a cellular level, disruptions of protein trafficking and recycling, particularly by misfolding, accumulation, and aggregation of $\alpha$-synuclein, mitochondrial dysfunction, oxidative stress, and other etiopathogenic mechanisms, have been found to result in the death of vulnerable neuronal populations and appear to drive the neurodegeneration underlying Parkinson's disease. The improved understanding of these mechanisms has led to the development of novel pathogenesis-targeted and potentially disease-modifying therapeutic approaches in Parkinson's disease. Until these treatments are fully developed and approved, clinicians must rely on therapies designed to improve quality of life of patients by treating various motor and non-motor symptoms of the disease.
\end{abstract}

\section{Keywords}

Parkinson's Disease, emerging treatment, pathogenesis

\section{Peer Review}

The peer reviewers who approve this article are:

1. Aideen M Sullivan, Department of Anatomy and Neuroscience and Cork Neuroscience Centre, University College Cork, Cork, Ireland

Competing interests: No competing interests were disclosed.

2. Maria-Rosario Luquin, Movement Disorders Unit, Clínica Universidad de Navarra (CUN), 31008 Pamplona, Spain Competing interests: No competing interests were disclosed.

3. Gianni Pezzoli, Fondazione Grigioni per il Morbo di Parkinson, Milan, Italy; Parkinson Institute, ASST “Gaetano Pini-CTO, Milan, Italy

Competing interests: No competing interests were disclosed. 
*Corresponding author: Joseph Jankovic (josephj@bcm.edu)

Competing interests: JJ has received research/training funding from AbbVie, Acadia Pharmaceuticals, Allergan, Biotek, Cerevel Therapeutics, the CHDI Foundation, Dystonia Coalition, Emalex Biosciences, F. Hoffmann-La Roche, the Huntington Study Group, Medtronic Neuromodulation, Merz Pharmaceuticals, the Michael J Fox Foundation for Parkinson Research, the National Institutes of Health, Neuraly, Neurocrine Biosciences, the Parkinson's Foundation, the Parkinson Study Group, Prilenia Therapeutics, Revance Therapeutics, and Teva Pharmaceutical Industries. He has served as consultant or advisory board member for Aeon BioPharma, Nuvelution Pharma, and Teva Pharmaceutical Industries and as an editorial board member of Expert Review of Neurotherapeutics, Journal of Parkinson's Disease, Medlink, Neurology in Clinical Practice, the Botulinum Journal, PeerJ, Therapeutic Advances in Neurological Disorders, Toxins, Tremor and Other Hyperkinetic Movements, and UpToDate. He has received royalties from Cambridge, Elsevier, Medlink: Neurology, Lippincott Williams and Wilkins, and Wiley-Blackwell. AT declares that he has no competing interests.

Grant information: The authors declare that no grants were involved in supporting this work.

Copyright: $\odot 2020$ Jankovic J et al. This is an open access article distributed under the terms of the Creative Commons Attribution License, which permits unrestricted use, distribution, and reproduction in any medium, provided the original work is properly cited.

How to cite this article: Tarakad A and Jankovic J. Recent advances in understanding and treatment of Parkinson's disease. Faculty Reviews 2020 9:(6) https://doi.org/10.12703/E[9-6

Published: 10 Nov 2020, Faculty Reviews 9:(6) https://doi.org/10.12703/E]9-6 


\section{Introduction}

Parkinson's disease (PD) is a neurodegenerative disorder classically characterized by a combination of rest tremor, slowness (bradykinesia), increased muscle tone (rigidity), and impairment of gait and balance. In addition to exhibiting these cardinal motor symptoms, patients with PD can exhibit a wide array of motor and non-motor symptoms, including changes in posture and other skeletal deformities (for example, "striatal hands"), loss of sense of smell and taste, autonomic dysfunction, mood disturbances, cognitive impairment, sleep disturbances, and pain. Although the disorder has long been considered to be a primarily sporadic disorder (despite frequent family history of PD), the identification of numerous PD-related genes since the late 1990s has changed this perception and definition of $\mathrm{PD}^{1}$. Indeed, many now view PD as a syndrome with different pathogenic mechanisms producing characteristic or atypical symptoms. Genetic susceptibility coupled with environmental factors and aging seems to drive the development of $\mathrm{PD}^{2}$.

In line with this changing perception of PD to a syndrome, there has been increasing interest in identifying PD "subtypes" based on clinical phenotype, underlying genotype, and pathology ${ }^{3}$. Of course, the ultimate goals are to better understand that pathogenesis and develop disease-specific and progression biomarkers that will lead to individualized symptomatic and disease-modifying therapies ${ }^{4}$.

In this review, we briefly discuss the most common PD-related genes along with proposed mechanisms of etiopathogenesis based on affected pathways and the role of environmental exposure in the development of PD. We also highlight new findings related to the interaction between gut and brain. We then discuss recent advances in the development of potential disease-modifying therapies and more personalized treatment.

\section{Genetics in Parkinson's disease}

About 5 to $10 \%$ of patients with PD have a monogenic form of the disease following classic Mendelian inheritance patterns, and the remaining cases are felt to be sporadic, although over 100 susceptibility genes and risk-associated gene variants have been identified ${ }^{5,6}$. Many of these gene variants are linked to pathways involved in autophagy and lysosomal biology and other cellular mechanisms that impair clearance of rogue proteins, such as $\alpha$-synuclein.

After the 1997 discovery of the gene that codes for $\alpha$-synuclein $(S N C A)$ and subsequent identification of $\alpha$-synuclein as the major component in Lewy bodies (the hallmark pathologic finding in PD), basic and clinical research shifted focus on this protein as one of the important factors in understanding the pathogenesis of neurodegeneration in $\mathrm{PD}^{2,7,8}$. Oligomerization of $\alpha$-synuclein as a result of mutant $S N C A$ and accumulation of excess protein due to duplication or triplication of the SNCA gene have been postulated as mechanisms of PD in these rare patients with $S N C A$ mutations or multiplications, although this concept of $\alpha$-synuclein as a toxic protein has been extended to other forms of PD, including "idiopathic". As oligomeric $\alpha$-synuclein continues to aggregate, it becomes insoluble and forms $\beta$ sheet-rich amyloid aggregates that impair cell function? 9 . This $\alpha$-synuclein pathology spreads and propagates in a prion-like fashion. Indeed, prion-like spread has been postulated as a mechanism of progression in many neurodegenerative diseases besides PD (synucleinopathies and other proteinopathies) $)^{10-12}$.

Mutation in the LRRK2 gene, encoding for leucine-rich repeat kinase 2 protein, first mapped in $2002^{13}$, is much more commonly implicated than SNCA, accounting for $4 \%$ of familial and $1 \%$ of sporadic cases of PD, but in certain populations may account for up to $10 \%$ of all "sporadic" PD and $42 \%$ of familial cases in Europe and North Africa, particularly in North African Berbers, Iberian populations, and Ashkenazi Jews $(13 \% \text { sporadic and } 30 \% \text { familial })^{14,15}$. It is worth noting that LRRK2 mutations show a great degree of phenotypic and pathologic heterogeneity as well as variable penetrance, ranging from 20 to $100 \%$. This variability is not readily explained by the specific mutations.

Several genes, when mutated, can affect mitochondrial function and result in a PD phenotype. The Parkin gene mutations are associated with younger-onset recessively inherited PD, accounting for 10 to $50 \%$ of cases of PD with onset before 50 years of age ${ }^{16,17}$. A notable pathologic feature includes the paucity of Lewy bodies as compared with idiopathic $\mathrm{PD}^{18}$. Mechanistically, the Parkin protein is involved in ubiquitination and protein recycling and plays an important role in mitochondrial homeostasis ${ }^{19}$. The PINK1 gene encodes for phospatin and tensin (PTEN) homolog-induced kinase 1, a protein that localizes to mitochondria and associates with the ubiquitinating Parkin protein to regulate mitophagy ${ }^{19,20}$. The $D J-1$ gene encodes a peptidase that protects against oxidation, and mutations in the gene are associated with altered mitochondrial morphology ${ }^{5,21}$. Both PINK1 and DJ-1 mutations result in a recessively inherited young-onset PD clinically similar to the Parkin phenotype ${ }^{1}$. The growing understanding of the role of mitochondria, highly concentrated in striatal nerve terminals, has led to an evolving concept that PD represents an axonopathy with initial axonal arborization and mitochondrial dysfunction in the striatum with subsequent striatal-nigral degeneration ${ }^{22-24}$.

The VPS35 gene encoding vacuolar sorting protein 35 is associated with an autosomal dominant form of PD showing reduced penetrance and late onset of disease ${ }^{5,25,26}$. VPS35 is a subunit of a protein complex known as the retromer, which is involved in recycling of membrane proteins through association with endosomes and facilitation of transport to the trans-Golgi network or plasma membrane. VPS35 dysfunction results in enhanced accumulation of insoluble $\alpha$-synuclein and disruption in mitochondrial function and turnover ${ }^{26}$.

Mutations in $G B A$, the gene encoding glucocerebrosidase, have been associated with the recessively inherited lysosomal storage disorder Gaucher's disease. This gene has been garnering increasing attention because of growing recognition of a high prevalence in certain PD populations; as much as 10 
to $15 \%$ of sporadic cases and over $40 \%$ of familial cases in the Ashkenazi Jewish population carry the GBA gene mutation ${ }^{27}$. Several other genes have been implicated in lysosomal storage disorders and have been associated with risk of developing PD $^{28,29}$.

Genome-wide association studies have expanded the number of loci associated with increased genetic risk of PD and have explained 11 to $15 \%$ of the heritable risk of $\mathrm{PD}^{6,30}$. It is likely that additional genes will be identified in the future and will provide further evidence of heritability of PD, but the challenge will be to explain how these genetic risks translate into clinical and pathological phenotypes ${ }^{31}$.

\section{Extrinsic factors in Parkinson's disease}

A causal role of an environmental factor in PD is often difficult to prove. This is because, as with other neurodegenerative disorders, inciting events in the disease process may predate clinical symptoms by years or even decades. Several environmental factors, including pesticide exposure, rural living, and heavy metal exposure, have been associated with an increased risk of developing $\mathrm{PD}^{32}$. Furthermore, consumption of dairy products, exposure to methamphetamine, and co-morbid medical conditions such as type 2 diabetes mellitus, autoimmune disorders, traumatic brain injury, or melanoma have been associated with increased risk of developing of $\mathrm{PD}^{32,33}$. In contrast, cigarette smoking, caffeine consumption, and green and black tea consumption appear to confer a reduced risk of PD development ${ }^{32}$. Beta blockers have been proposed to increase the risk of developing PD, whereas beta agonists have been suggested as protective, possibly through proposed up- and down-regulation of SNCA expression, respectively ${ }^{34,35}$, although some population-based studies have failed to show this correlation ${ }^{36}$. Low uric acid levels have also been associated with an increased risk of PD across many studies $^{37,38}$, although recent biomarker studies have challenged this observation ${ }^{39}$.

\section{Gut-brain relationship}

The gastrointestinal system has been known to be involved in PD, as evidenced by the frequent occurrence of constipation even during the prodromal phase, but its role in the pathogenesis of PD was not recognized until quite recently. One of the leading hypotheses behind the progression of PD is the transmission of synuclein pathology from the periphery through olfactory neurons and from the enteric nervous system via the vagus nerve, followed by centripetal spread to the substantia nigra; this is the so-called dual-hit hypothesis proposed by Braak and colleagues ${ }^{40}$. The finding of $\alpha$-synuclein aggregates in the gastrointestinal tract supports the notion of spread of synuclein pathology from the gut via the vagus nerve to the caudal brainstem and then rostrally to the substantia nigra, diencephalon, and neocortex ${ }^{24,40-42}$. Further support for the involvement of the gut and the vagus nerve in the pathogenesis and progression of PD are studies that demonstrate a modest protective effect of vagotomy in the development of $\mathrm{PD}^{43,44}$. The make-up of gut microbiota has been shown to differ in PD patients relative to healthy controls and may even correlate with disease severity and symptoms ${ }^{44-46}$, raising the possibility that different gut microbiota contribute to the etiopathogenesis of the disease $\mathrm{e}^{47}$.

Although $\alpha$-synuclein has been at the center stage as a key protein implicated in the pathogenesis of PD, it is worth noting that its pivotal role and the hypothesis of Braak and colleagues have been challenged ${ }^{48}$. For example, it is important to note that the staging of Braak and colleagues is based on Lewy body pathology rather than neuronal loss and that up to a third of patients do not show Lewy body pathology in the enteric system. Finally, some have suggested that protein aggregation represents a compensatory response to cellular stress (epiphenomenon) $)^{49}$.

\section{Pathogenesis-targeted treatment strategies in Parkinson's disease}

One of the outcomes of improved understanding of pathogenic mechanisms underlying PD is the development of more targeted treatments toward these mechanisms ${ }^{8}$. For example, there has been a great deal of interest in antibodies targeting $\alpha$-synuclein ${ }^{50,51}$, given its prevalence and presumed pathogenic role in a majority of cases of PD. Other potential disease-modifying treatments being investigated in PD include glucagon-like peptide-1 receptor agonists (currently used in treatment of diabetes), nilotinib (a chemotherapeutic agent) and its analogs, and numerous gut dysbiosis trials aiming to "normalize" gut microbiota of patients with PD (Table 1) $)^{2,52-55}$.

Though not pathogenesis-targeted treatments per se, a number of new dopamine replacement strategies, including adenoassociated virus-mediated gene therapy to boost dopamine production in surviving neurons, exogenously induced dopaminergic neuron precursor cells, or even the conversion of astrocytes into neuronal cell populations, represent exciting new prospects for the field of PD therapeutics ${ }^{56-59}$. Also, cellbased therapies, including autologous-induced pluripotent stem cells, are being intensely investigated as potential therapies in $\mathrm{PD}^{60}$.

There is a growing body of evidence that PD is not a single clinical-pathological entity but a syndrome consisting of multiple disease states with different underlying mechanisms of neurodegeneration, hence requiring a specific (personalized) therapeutic approach ${ }^{61}$. Furthermore, even within PD, there may be subtypes, such as the tremor dominant subtype, postural instability and gait difficulty (PIGD) subtype, and other subtypes $^{3,62}$. Beyond these subtypes, different genetic forms of PD also demonstrate unique or characteristic phenotypes, including age at onset, presence of dystonia and other movement disorders, development of complications to levodopa therapy, deep brain stimulation (DBS) responsiveness, and a degree of associated cognitive impairment ${ }^{1}$. Better understanding of underlying disease mechanisms as well as identification of different phenotypes by genetic analysis opens the door to incorporating subtype-specific, personalized treatments in $\mathrm{PD}^{3,31,49}$. Research into such experimental therapies, such as LRRK2 


\begin{tabular}{|c|c|c|c|c|}
\hline Category & $\begin{array}{l}\text { Treatment } \\
\text { agent(s) }\end{array}$ & $\begin{array}{l}\text { ClinicalTrials.gov } \\
\text { Identifiers }\end{array}$ & $\begin{array}{l}\text { Trial } \\
\text { phase }\end{array}$ & Proposed mechanism of action \\
\hline \multirow[t]{2}{*}{$\begin{array}{l}\text { Alpha-synuclein } \\
\text { immunotherapy }\end{array}$} & $\begin{array}{l}\text { PRX002 } \\
\text { BIIB054 } \\
\text { ABBV-0805 }\end{array}$ & $\begin{array}{l}\text { NCT03100149 } \\
\text { NCT03318523 } \\
\text { NCT03716570 } \\
\text { NCT04127695 }\end{array}$ & $\begin{array}{l}\text { Phase } 2 \\
\text { Phase } 2 \\
\text { Phase } 1 \\
\text { Phase } 1\end{array}$ & $\begin{array}{l}\text { Passive immunization via infused alpha- } \\
\text { synuclein antibodies }\end{array}$ \\
\hline & $\begin{array}{l}\text { PD01A } \\
\text { PD03A }\end{array}$ & $\begin{array}{l}\text { NCT01568099 } \\
\text { NCT02618941 } \\
\text { NCT02267434 }\end{array}$ & $\begin{array}{l}\text { Phase } 1 \\
\text { Phase } 1 \\
\text { Phase } 1\end{array}$ & $\begin{array}{l}\text { Active immunization via administration of } \\
\text { synthetic peptide sequences }\end{array}$ \\
\hline Tyrosine kinase inhibitor & $\begin{array}{l}\text { Nilotinib } \\
\text { K0706 }\end{array}$ & $\begin{array}{l}\text { NCT03205488 } \\
\text { NCT02954978 } \\
\text { NCT03655236 }\end{array}$ & $\begin{array}{l}\text { Phase } 2 \\
\text { Phase } 2 \\
\text { Phase } 2\end{array}$ & $\begin{array}{l}\text { Inhibition of Abelson tyrosine kinase } \\
\text { (which inhibits Parkin) }\end{array}$ \\
\hline $\begin{array}{l}\text { Glucagon-like peptide } 1 \\
\text { agonist }\end{array}$ & $\begin{array}{l}\text { Exenatide } \\
\text { Semaglutide } \\
\text { Liraglutide }\end{array}$ & $\begin{array}{l}\text { NCT04269642 } \\
\text { NCT04305002 } \\
\text { NCT04154072 } \\
\text { NCT04232969 } \\
\text { NCT03659682 } \\
\text { NCT02953665 }\end{array}$ & $\begin{array}{l}\text { Phase } 2 \\
\text { Phase } 2 \\
\text { Phase } 2 \\
\text { Phase } 3 \\
\text { Phase } 2 \\
\text { Phase } 2\end{array}$ & $\begin{array}{l}\text { Acts on MAP kinase and PI3 kinase to } \\
\text { decrease neuroinflammation }\end{array}$ \\
\hline \multirow[t]{2}{*}{ Gut dysbiosis } & Fecal transplant & $\begin{array}{l}\text { NCT03671785 } \\
\text { NCT03876327 } \\
\text { NCT03808389 }\end{array}$ & $\begin{array}{l}\text { Phase } 1 \\
\text { Phase 2/3 } \\
--\end{array}$ & $\begin{array}{l}\text { Microbiota transfer via fecal } \\
\text { transplantation from healthy donor }\end{array}$ \\
\hline & $\begin{array}{l}\text { Resistant } \\
\text { maltodextrin }\end{array}$ & NCT03667404 & Phase 2 & $\begin{array}{l}\text { Prebiotic treatment to regulate gut } \\
\text { microbiome }\end{array}$ \\
\hline \multirow[t]{2}{*}{$\begin{array}{l}\text { Glucocerebrosidase-targeted } \\
\text { therapy }\end{array}$} & Ambroxol & NCT02914366 & Phase 2 & $\begin{array}{l}\text { Increase levels of beta- } \\
\text { glucocerebrosidase to lower alpha- } \\
\text { synuclein levels }\end{array}$ \\
\hline & PR001A & NCT04127578 & Phase $1 / 2 a$ & $\begin{array}{l}\text { GBA gene delivered to neurons via viral } \\
\text { vector }\end{array}$ \\
\hline
\end{tabular}

inhibitors and treatments targeting enhancement of glucocerebrosidase activity or facilitating substrate clearance in $G B A$-associated PD, has already reached planning and trial phases $^{28}$.

One of many challenges in the development of diseasemodifying therapies has been marked paucity of clinical, biochemical, or imaging markers that reliably track the progression of the disease ${ }^{63}$. The clinical gold standard for assessing severity of PD symptoms and signs, the UPDRS or the MDSUPDRS, used in nearly all clinical trials as a primary outcome measure, has many limitations, including marked within-subject variability ${ }^{64}$. Technology has also started to play an increasing role in PD diagnosis and treatment with the hope of finding digital biomarkers that may allow earlier detection of PD or further discrimination among subtypes. However, difficulty in interpretation of gathered data and lack of standardization across device platforms are current barriers to widespread reliable usage ${ }^{65,66}$.

\section{Conclusions}

Recent years have witnessed a dramatic increase in our understanding of genetics in PD and consequently an improved understanding of pathogenic and pathophysiologic mechanisms of the disease. These include discoveries about $\alpha$-synuclein and its role as a "rogue protein", reduced protein clearance, mitochondrial dysfunction, and oxidative stress. We are entering an exciting era during which the improved knowledge about cellular and molecular mechanisms underlying neurodegeneration in $\mathrm{PD}$ is translated into pathogenesis-specific, disease-modifying treatments in PD and a more personalized approach designed to slow or prevent progression of the disease and improve quality of life of patients with PD. 
1. Domingo A, Klein C: Genetics of Parkinson disease. Handb Clin Neurol. 2018; 147: 211-27.

PubMed Abstract | Publisher Full Text | Faculty Opinions Recommendation

2. Jankovic J, Tan EK: Parkinson's disease: etiopathogenesis and treatment. J Neurol Neurosurg Psychiatry. 2020; 91(8): 795-808.

PubMed Abstract | Publisher Full Text

3. Thenganatt MA, Jankovic J: Parkinson disease subtypes. JAMA Neurol. 2014; 71(14): 499-504

PubMed Abstract | Publisher Full Text

4. Espay AJ, Kalia LV, Gan-Or Z, et al:: Disease modification and biomarker development in Parkinson disease: Revision or reconstruction? Neurology. 2020; 94(11): 481-94.

PubMed Abstract | Publisher Full Text | Free Full Text

5. Deng H, Wang P, Jankovic J: The genetics of Parkinson disease. Ageing Res Rev. 2018; 42: 72-85.

PubMed Abstract | Publisher Full Text

6. CBlauwendraat $C$, Nalls MA, Singleton $A B$ : The genetic architecture of Parkinson's disease. Lancet Neurol. 2020; 19(2): 170-8. PubMed Abstract | Publisher Full Text | Faculty Opinions Recommendation

7. Polymeropoulos $\mathrm{MH}$, Lavedan $\mathrm{C}$, Leroy $\mathrm{E}$, et al:: Mutation in the alpha-synuclein gene identified in families with Parkinson's disease. Science. 1997; 276(5321): 2045-7.

PubMed Abstract | Publisher Full Text

8. Armstrong MJ, Okun MS: Diagnosis and Treatment of Parkinson Disease: A Review. JAMA. 2020; 323(6): 548-560.

PubMed Abstract | Publisher Full Text | Faculty Opinions Recommendation

9. Balestrino R, Schapira AHV: Parkinson disease. Eur J Neurol. 2020; 27(1): $27-42$.

PubMed Abstract | Publisher Full Text | Faculty Opinions Recommendation

10. Jaunmuktane Z, Brandner S: Invited Review: The role of prion-like mechanisms in neurodegenerative diseases. Neuropathol Appl Neurobiol. 2020; 46(6): 522-545.

PubMed Abstract | Publisher Full Text

11. McAlary L, Plotkin SS, Yerbury JJ, et al.: Prion-Like Propagation of Protein Misfolding and Aggregation in Amyotrophic Lateral Sclerosis. Front Mol Neurosci. 2019; 12: 262

PubMed Abstract | Publisher Full Text | Free Full Text

12. Rösener NS, Gremer L, Wördehoff MM, et al.: Clustering of human prion protein and $\alpha$-synuclein oligomers requires the prion protein $\mathrm{N}$-terminus. Commun Biol. 2020; 3(1): 365 .

PubMed Abstract | Publisher Full Text | Free Full Text

13. Funayama $\mathrm{M}$, Hasegawa $\mathrm{K}$, Kowa $\mathrm{H}$, et al.: A new locus for Parkinson's disease (PARK8) maps to chromosome 12p11.2-q13.1. Ann Neurol. 2002; 51(3): 296-301.

PubMed Abstract | Publisher Full Text

14. Healy DG, Falchi M, O'Sullivan SS, et al:: Phenotype, genotype, and worldwide genetic penetrance of LRRK2-associated Parkinson's disease: a case-control study. Lancet Neurol. 2008; 7(7): 583-90.

PubMed Abstract | Publisher Full Text | Free Full Text

15. Simuni T, Uribe L, Cho HR, et al:: Clinical and dopamine transporter imaging characteristics of non-manifest LRRK2 and GBA mutation carriers in the Parkinson's Progression Markers Initiative (PPMI): a cross-sectional study. Lancet Neurol. 2020; 19(1): 71-80.

PubMed Abstract | Publisher Full Text | Free Full Text

16. Niemann N, Jankovic J: Juvenile parkinsonism: Differential diagnosis, genetics, and treatment. Parkinsonism Relat Disord. 2019; 67: 74-89. PubMed Abstract | Publisher Full Text

17. Mehanna R, Jankovic J: Young-onset Parkinson's disease: Its unique features and their impact on quality of life. Parkinsonism Relat Disord. 2019; 65: 39-48. PubMed Abstract | Publisher Full Text

18. Doherty KM, Silveira-Moriyama L, Parkkinen L, et al:: Parkin disease: a clinicopathologic entity? JAMA Neurol. 2013; 70(5): 571-9. PubMed Abstract | Publisher Full Text | Free Full Text | Faculty Opinions Recommendation

19. Arkinson C, Walden H: Parkin function in Parkinson's disease. Science. 2018; 360(6386): 267-8.

PubMed Abstract | Publisher Full Text

20. Pickrell AM, Youle RJ: The roles of PINK1, parkin, and mitochondrial fidelity in Parkinson's disease. Neuron. 2015; 85(2): 257-73. PubMed Abstract | Publisher Full Text | Free Full Text | Faculty Opinions Recommendation

21. Vvan der Vlag M, Havekes R, Heckman PRA: The contribution of Parkin, PINK1 and DJ-1 genes to selective neuronal degeneration in Parkinson's disease. Eur J Neurosci. 2020; 52(4): 3256-68

PubMed Abstract | Publisher Full Text | Free Full Text |

Faculty Opinions Recommendation
22. O'Keeffe GW, Sullivan AM: Evidence for dopaminergic axonal degeneration as an early pathological process in Parkinson's disease. Parkinsonism Relat Disord. 2018; 56: 9-15.

PubMed Abstract | Publisher Full Text | Faculty Opinions Recommendation

23. Wong YC, Luk K, Purtell K, et al:: Neuronal vulnerability in Parkinson disease: Should the focus be on axons and synaptic terminals? Mov Disord. 2019; 34(10): 1406-22.

PubMed Abstract | Publisher Full Text | Free Full Text |

Faculty Opinions Recommendation

24. Surmeier DJ, Obeso JA, Halliday GM: Selective neuronal vulnerability in Parkinson disease. Nat Rev Neurosci. 2017; 18(2): 101-13. PubMed Abstract | Publisher Full Text | Free Full Text | Faculty Opinions Recommendation

25. Deng H, Gao K, Jankovic J: The VPS35 gene and Parkinson's disease. Mov Disord. 2013; 28(5): 569-75.

PubMed Abstract | Publisher Full Text

26. Williams ET, Chen X, Moore DJ: VPS35, the Retromer Complex and Parkinson's Disease. J Parkinsons Dis. 2017; 7(2): 219-33. PubMed Abstract | Publisher Full Text | Free Full Text | Faculty Opinions Recommendation

27. Gan-Or Z, Liong C, Alcalay RN: GBA-Associated Parkinson's Disease and Other Synucleinopathies. Curr Neurol Neurosci Rep. 2018; 18(8): 44. PubMed Abstract | Publisher Full Text | Faculty Opinions Recommendation

28. Y Ysselstein D, Shulman JM, Krainc D: Emerging links between pediatric lysosomal storage diseases and adult parkinsonism. Mov Disord.. 2018; 34(5): $614-24$

PubMed Abstract | Publisher Full Text | Free Full Text |

Faculty Opinions Recommendation

29. Robak LA, Jansen IE, van Rooij J, et al:: Excessive burden of lysosomal storage disorder gene variants in Parkinson's disease. Brain. 2017; 140(12): 3191-203. PubMed Abstract | Publisher Full Text | Free Full Text

30. Nalls MA, Blauwendraat $\mathrm{C}$, Vallerga $\mathrm{CL}$, et al.: Identification of novel risk loci, causal insights, and heritable risk for Parkinson's disease: a meta-analysis of genome-wide association studies. Lancet Neurol. 2019; 18(12): 1091-102. of genome-wide association studies.
PubMed Abstract | Publisher Full Text

31. Bandres-Ciga S, Diez-Fairen M, Kim JJ, et al.: Genetics of Parkinson's disease: An introspection of its journey towards precision medicine. Neurobiol Dis. 2020; 137: 104782

PubMed Abstract | Publisher Full Text | Free Full Text |

Faculty Opinions Recommendation

32. Ascherio A, Schwarzschild MA: The epidemiology of Parkinson's disease: risk factors and prevention. Lancet Neurol. 2016; 15(12): 1257-72. PubMed Abstract | Publisher Full Text | Faculty Opinions Recommendation

33. Tan EK, Chao YX, West A, et al.: Parkinson disease and the immune system - associations, mechanisms and therapeutics. Nat Rev Neurol. 2020; 16(6): 303-18.

PubMed Abstract | Publisher Full Text

34. Mittal S, Bjørnevik K, Im DS, et al.: $\beta 2$-Adrenoreceptor is a regulator of the $\alpha$-synuclein gene driving risk of Parkinson's disease. Science. 2017; 357(6354): 891-8.

PubMed Abstract | Publisher Full Text | Free Full Text |

Faculty Opinions Recommendation

35. Koren G, Norton G, Radinsky K, et al:: Chronic Use of $\beta$-Blockers and the Risk of Parkinson's Disease. Clin Drug Investig. 2019; 39(5): 463-8. PubMed Abstract | Publisher Full Text | Faculty Opinions Recommendation

36. Searles Nielsen S, Gross A, Camacho-Soto A, et al.: $\beta 2$-adrenoreceptor medications and risk of Parkinson disease. Ann Neurol. 2018; 84(5): 683-93. PubMed Abstract | Publisher Full Text | Free Full Text | Faculty Opinions Recommendation

37. Wen M, Zhou B, Chen YH, et al.: Serum uric acid levels in patients with Parkinson's disease: A meta-analysis. PLoS One. 2017; 12(3): e0173731. PubMed Abstract | Publisher Full Text | Free Full Text

38. Vvan Wamelen DJ, Taddei RN, Calvano A, et al:: Serum Uric Acid Levels and Non-Motor Symptoms in Parkinson's Disease. J Parkinsons Dis. 2020; 10(3): 1003-10.

PubMed Abstract | Publisher Full Text | Faculty Opinions Recommendation

39. Lawton M, Baig F, Toulson G, et al.: Blood biomarkers with Parkinson's disease clusters and prognosis: The oxford discovery cohort. Mov Disord. 2020; 35(2): 279-87.

PubMed Abstract | Publisher Full Text | Free Full Text |

Faculty Opinions Recommendation

40. Hawkes $\mathrm{CH}$, Del Tredici K, Braak H: Parkinson's disease: A dual-hit hypothesis. Neuropathol Appl Neurobiol. 2007; 33(6): 599-614.

PubMed Abstract | Publisher Full Text | Free Full Text 
41. Borghammer P: How does parkinson's disease begin? Perspectives on neuroanatomical pathways, prions, and histology. Mov Disord. 2018; 33(1): 48-57.

PubMed Abstract | Publisher Full Text | Faculty Opinions Recommendation

42. Peng C, Trojanowski JQ, Lee VMY: Protein transmission in neurodegenerative disease. Nat Rev Neurol. 2020; 16(4): 199-212. PubMed Abstract | Publisher Full Text | Faculty Opinions Recommendation

43. S Scheperjans F, Derkinderen P, Borghammer P: The Gut and Parkinson's Disease: Hype or Hope? J Parkinsons Dis. 2018; 8(s1): S31-S39. PubMed Abstract | Publisher Full Text | Free Full Text | Faculty Opinions Recommendation

44. Barichella M, Severgnini M, Cilia R, et al.: Unraveling gut microbiota in Parkinson's disease and atypical parkinsonism. Mov Disord. 2019; 34(3): 396-405.

PubMed Abstract | Publisher Full Text | Faculty Opinions Recommendation

45. Minato T, Maeda T, Fujisawa Y, et al:: Progression of Parkinson's disease is associated with gut dysbiosis: Two-year follow-up study. PLoS One. 2017 12(11): e0187307.

PubMed Abstract | Publisher Full Text | Free Full Text |

Faculty Opinions Recommendation

46. Elfil M, Kamel S, Kandil M, et al.: Implications of the Gut Microbiome in Parkinson's Disease. Mov Disord. 2020; 35(6): 921-33. PubMed Abstract | Publisher Full Text | Faculty Opinions Recommendation

47. Breen DP, Halliday GM, Lang AE: Gut-brain axis and the spread of $\alpha$ synuclein pathology: Vagal highway or dead end? Mov Disord. 2019; 34(3): 307-16.

PubMed Abstract | Publisher Full Text | Faculty Opinions Recommendation

48. Rietdijk CD, Perez-Pardo P, Garssen J, et al.: Exploring Braak's Hypothesis of Parkinson's Disease. Front Neurol. 2017; 8: 37. PubMed Abstract | Publisher Full Text | Free Full Text

49. Espay AJ, Vizcarra JA, Marsili L, et al.: Revisiting protein aggregation as pathogenic in sporadic Parkinson and Alzheimer diseases. Neurology. 2019; 92(7): 329-37.

PubMed Abstract | Publisher Full Text | Free Full Text | Faculty Opinions Recommendation

50. Henderson MX, Covell DJ, Chung CHY, et al:: Characterization of novel conformation-selective $\alpha$-synuclein antibodies as potential immunotherapeutic agents for Parkinson's disease. Neurobiol Dis. 2020; 136: 104712. PubMed Abstract | Publisher Full Text | Free Full Text | Faculty Opinions Recommendation

51. Savitt D, Jankovic J: Targeting $\alpha$-Synuclein in Parkinson's Disease: Progress Towards the Development of Disease-Modifying Therapeutics. Drugs. 2019; 79(8): 797-810. PubMed Abstract | Publisher Full Text

52. Athauda D, Maclagan K, Budnik N, et al: Post hoc analysis of the ExenatidePD trial-Factors that predict response. Eur J Neurosci. 2019; 49(3): 410-21. PubMed Abstract | Publisher Full Text | Faculty Opinions Recommendation

53. Pagan FL, Hebron ML, Wilmarth B, et al:: Nilotinib Effects on Safety, Tolerability, and Potential Biomarkers in Parkinson Disease: A Phase 2 Randomized Clinical Trial. JAMA Neurol. 2019; 77(3): 309-317. PubMed Abstract | Publisher Full Text | Free Full Text | Faculty Opinions Recommendation
54. Guttuso T, Andrzejewski KL, Lichter DG, et al.: Targeting kinases in Parkinson's disease: A mechanism shared by LRRK2, neurotrophins, exenatide, urate, nilotinib and lithium. J Neurol Sci. 2019; 402: 121-30. PubMed Abstract | Publisher Full Text | Faculty Opinions Recommendation

55. Dutta SK, Verma S, Jain V, et al.: Parkinson's Disease: The Emerging Role of Gut Dysbiosis, Antibiotics, Probiotics, and Fecal Microbiota Transplantation. J Neurogastroenterol Motil. 2019; 25(3): 363-76.

PubMed Abstract | Publisher Full Text | Free Full Text | Faculty Opinions Recommendation

56. Piguet F, Alves S, Cartier N: Clinical Gene Therapy for Neurodegenerative Diseases: Past, Present, and Future. Hum Gene Ther. 2017; 28(11): 988-1003. PubMed Abstract | Publisher Full Text

57. Darmar M, Grealish S, Henchcliffe C: The future of stem cell therapies for Parkinson disease. Nat Rev Neurosci. 2020; 21(2): 103-15. PubMed Abstract | Publisher Full Text | Faculty Opinions Recommendation

58. Arenas E: Method to combat Parkinson's disease by astrocyte-to-neuron conversion. Nature. 2020; 582(7813): 489-90. PubMed Abstract | Publisher Full Text | Faculty Opinions Recommendation

59. Q Qian H, Kang X, Hu J, et al.: Reversing a model of Parkinson's disease with in situ converted nigral neurons. Nature. 2020; 582(7813): 550-6. PubMed Abstract | Publisher Full Text | Free Full Text | Faculty Opinions Recommendation

60. Jankovic J, Okun MS, Kordower JH: Stem Cells: Scientific and Ethical Quandaries of a Personalized Approach to Parkinson's Disease. Mov Disord. 2020; 35(8): 1312-4.

PubMed Abstract | Publisher Full Text

61. Titova N, Padmakumar C, Lewis SJG, et al.: Parkinson's: A syndrome rather than a disease? J Neural Transm. 2017; 124(8): 907-14. PubMed Abstract | Publisher Full Text | Free Full Text | Faculty Opinions Recommendation

62. Co Pablo-Fernández E, Lees AJ, Holton JL, et al.: Prognosis and Neuropathologic Correlation of Clinical Subtypes of Parkinson Disease. JAMA Neurol. 2019; 76(4): 470-9.

PubMed Abstract | Publisher Full Text | Free Full Text | Faculty Opinions Recommendation

63. Tarakad A: Clinical Rating Scales and Quantitative Assessments of Movement Disorders. Neurol Clin. 2020; 38(2): 231-54. PubMed Abstract | Publisher Full Text

64. Evers LJW, Krijthe JH, Meinders MJ, et al.: Measuring Parkinson's disease over time: The real-world within-subject reliability of the MDS-UPDRS. Mov Disord. 2019; 34(10): 1480-7.

PubMed Abstract | Publisher Full Text | Free Full Text | Faculty Opinions Recommendation

65. Espay AJ, Bonato P, Nahab FB, et al:: Technology in Parkinson's disease: Challenges and opportunities. Mov Disord. 2016; 31(9): 1272-82. PubMed Abstract | Publisher Full Text | Free Full Text

66. Espay AJ, Hausdorff JM, Sánchez-Ferro Á, et al:: A roadmap for implementation of patient-centered digital outcome measures in Parkinson's disease obtained using mobile health technologies. Mov Disord. 2019; 34(5): 657-63.

PubMed Abstract | Publisher Full Text | Free Full Text |

Faculty Opinions Recommendation 